\title{
COMMENTS
}

\section{Post-Employment Restraint Agreements: A Reassessment}

( When hiring an employee who will have access to confidential business information, employers often include in the employment contract a provision restricting the employee's rights to use or disclose confidential information upon termination of employment ("post-employment restraint agreements"). Although an employee is in any case under an implied legal obligation not to disclose valuable business secrets, ${ }^{1}$ express agreements are used to put the employee on notice both as to the existence of the obligation ${ }^{2}$ and as to what information the employer considers confidential. ${ }^{3}$ Under

1 See, e.g., By-Buk Co. v. Printed Cellophane Tape Co., 163 Cal. App. 2d 157, 164, 329 P.2d 147, 151 (1958) ("Every employee is under the implied obligation not to divulge or use confidential information which he acquires by reason of his employment."). This obligation is often identified in cases involving the disclosure or use by former employees of secret manufacturing processes. See, e.g., E.I. Du Pont De Nemours Powder Co. v. Masland, 244 U.S. 100, 102 (1917) (breach of confidential relationship is threshold question in an action for theft of trade secrets against a former employee); Jet Spray Cooler, Inc. v. Crampton, 361 Mass. 835, 843-44, 282 N.E.2d 921, 926-27 (1972) (former employees of beverage-dispenser manufacturer breached duty of confidentiality by using a confidential report on product improvements, prepared for their former employer, in their own competing business); Junker v. Plummer, 320 Mass. 76, 80-81, 67 N.E.2d 667, 670 (1946) (relying on implied-contract theory to enjoin former employees from reproducing and using former employer's secret manufacturing processes); Glucol Mfg. Co. v. Schulist, 239 Mich. 70, 74-75, 214 N.W. 152, 153 (1927) (former employee enjoined from using former employer's secret manufacturing process in competing business).

2 See, e.g., Sperry Rand Corp. v. Rothlein, 241 F. Supp. 549, 554 (D. Conn. 1964) (confidentiality agreement "specified a part of the standard required by the duty of fidelity of each employee to the employer"); Kaumagraph Co. v. Stampagraph Co., 235 N.Y. 1, 6, 138 N.E. 485, 486 (1923) (post-employment restraint contracts "merely express the implied contract of one who enters into such an employment not to carry elsewhere into competition with his employer confidential knowledge obtained from him").

3 See, e.g., Hamilton Mfg. Co. v. Tubbs Mfg. Co., 216 F. 401, 407 (C.C.W.D. Mich. 1908) (notice to employee of information's secrecy a necessary element of trade-secret action); Eastern Marble Prods. Corp. v. Roman Marble, Inc., 372 Mass. 835, 840, 364 N.E.2d 799, 802 (1977) ("At the very least [the confidentiality agreement] put the employees on notice that secrets were involved."); Ultra-Life Laboratories, Inc. v. Eames, 240 Mo. App. $851,866,221$ S.W.2d 224, 232 (1949) (contract not to teach or divulge processes and meth- 
such a provision, an employee may agree not to work for a competitor of the employer or establish a competing business, ${ }^{4}$ or may agree to limit his disclosure of specified information in the event he continues to work in the industry. ${ }^{5}$

Modern American contract law, following the English common law, generally enforces agreements between competent parties. ${ }^{6}$ As a rule, therefore, courts will not engage in ex post inquiries regarding the substantive fairness of contract terms, ${ }^{7}$ partly because of the difficulties inherent in such subjective inquiries. ${ }^{8}$ Post-employment restraint agreements, however, have not been accorded this presumption of validity. Courts have viewed such agreements with disfavor for centuries, ${ }^{9}$ and the modern rule is that they will be

ods held an admission that such materials were secret).

4 See, e.g., National Hearing Aid Centers, Inc. v. Avers, 2 Mass. App. Ct. 285, 287, 311 N.E.2d 573, 575 (1974) (agreement not to sell hearing aids or accessories in a portion of New England for two years); Eastman Kodak Co. v. Powers Film Prods., Inc., 189 A.D. 556, 558, 179 N.Y.S. 325, 327 (1919) (agreement not to engage in photographic business for two years); Cas̀cade Exch., Inc. v. Reed, 278 Or. 749, 752, 565 P.2d 1095, 1096-97 (1977) (agreement not to compete in the truck-dispatching business for two years).

- See, e.g., Motorola, Inc. v. Fairchild Camera \& Instrument Corp., 366 F. Supp. 1173, 1183 (D. Ariz. 1973) (agreement not to disclose confidential information, including that related to the employer's products, costs, pricing practices, customer lists, and financial records, for two years); Wheelabrator Corp. v. Fogle, 317 F. Supp. 633, 635 (W.D. La. 1970) (agreement not to disclose "trade secrets, confidential procedures, data and drawings"); Glucol Mfg. Co. v. Schulist, 239 Mich. 70, 72-73, 214 N.W. 152, 152 (1927) (agreement never to disclose employer's formulas for manufacturing paste).

- See, e.g., Eldridge v. Johnston, 195 Or. 379, 405, 245 P.2d 239, 251 (1952) (public policy dictates that contracts between competent parties be enforced); 1 ARTHUR CorBIN, CoRBIN ON CONTRACTS $§ 127$ (1963) (courts will refuse to inquire into adequacy of consideration and will enforce contracts as written, unless fraud, mistake, or undue influence can be shown); cf. Epstein, Unconscionability: A Critical Reappraisal, 18 J.L. \& EcoN. 293, 293-94 (1975) (criticizing the increased willingness of courts to abandon the "classical conception of contract at common law [which] had as its first premise the belief that private agreements should be enforced in accordance with their terms").

${ }^{7}$ See Patrick Atiyah, The Rise and Fali of Freedom of Contract 398-405 (1979) (from 1770 to 1880, coincidence between general contract principles and free-market economic theory led to an emphasis on the bargaining process, rather than on the substantive fairness of the contract terms).

${ }^{3}$ See Richard A. Posner, Economic Analysis of Law 70 (2d ed. 1977).

- See, e.g., Reed, Roberts Assocs., Inc. v. Strauman, 40 N.Y.2d 303, 307, 353 N.E.2d $590,593,386$ N.Y.S.2d 677, 679 (1976) (disfavor results from " "powerful considerations of public policy" ") (quoting Purchasing Assocs. v. Weitz, 13 N.Y. 2d 267, 272, 196 N.E.2d 245, 247, 246, N.Y.S.2d 600, 604 (1963)); Kaumagraph Co. v. Stampagraph Co., 235 N.Y. 1, 9, 138 N.E. 485, 488 (1923) (courts of equity will enforce restrictive covenants only to the extent necessary to protect plaintiff's trade secrets); Kadis v. Britt, 224 N.C. 154, 160, 29 S.E.2d $543,546-47$ (1944) (citing the plight of the "needlessly pauperized" individual as justifying this disfavor); Mitchel v. Reynolds, 24 Eng. Rep. 347 (Ch. 1711); Clerk v. Governor \& Co. of Taylors of Exeter, 83 Eng. Rep. 670 (1685); The Blacksmiths of South Mims, 74 Eng. Rep. 485 (C.P. 1587). See generally William A. SANDERson, Restratnt of Trade in English LaW 7-47 (1926) (tracing the evolution of the modern approach to post-employment restraint 
enforced only to the extent that a court finds the agreement reasonable. ${ }^{10}$

The willingness of courts to make independent judgments about the reasonableness of post-employment restraints imposes significant costs that would be avoided by the general rule of nonintervention. A reasonableness inquiry entails the difficult assessment of an employer's commercial needs and an employee's subjective desires and preferences. An incorrect assessment of either may cause the invalidation of an economically beneficial agreement. Furthermore, the uncertain validity of these contracts creates an incentive for employees to breach the agreement, ${ }^{11}$ resulting in both misuse of valuable information and increased litigation. An employer, afraid of "guessing" wrong and thus compensating an employee for entering into an agreement that may later be held unenforceable, ${ }^{12}$ will be less willing to rely on such agreements and will require more of a wage sacrifice from employees who are given access to confidential information. Finally, to the extent that the reasonableness inquiry results in more involved court proceedings, litigation costs increase. Because of these costs, the differential treatment accorded post-employment restraint agreements requires a countervailing justification.

Courts have advanced three grounds to justify examining the

agreements).

10 See, e.g., Orkin Exterminating Co. v. Dewberry, 204 Ga. 794, 802, 51 S.E.2d 669, 675 (1949) ("While it is the general rule that a contract in general restraint of trade is void, a contract only in partial restraint may be upheld, 'provided the restraint be reasonable ... ." (quoting Kutash v. Gluckman, 193 Ga. 805, 807, 20 S.E.2d 128, 130 (1942)); American Broadcasting Cos. v. Wolf, 52 N.Y.2d 394, 404, 420 N.E.2d 363, 367-68, 438 N.Y.S.2d 482, 486-87 (1981) (express post-employment restraints are subjected to a reasonableness inquiry because of their potentially anticompetitive effect and their threat to the employee's ability to earn a living); Kadis v. Britt, 224 N.C. 154, 158, 29 S.E.2d 543, 545 (1944) (post-employment restraints are void unless shown to be reasonable); see also Handler \& Lazaroff, Restraint of Trade and the Restatement (Second) of Contracts, 57 N.Y.U. L. REv. 669, 755-56 (1982) (concluding, after exhaustive analysis of case law on contracts in restraint of trade, that "[a]ll ancillary restraints that are reasonable in purpose, geographic scope and duration are valid both at common law and under federal antitrust law, absent significant anticompetitive impact"); infra notes $28-35$ and accompanying text (discussing current approach to post-employment restraint agreements).

1 The employer necessarily discloses confidential information and performs its obligations under the contract before the employee has fulfilled his obligations. Thus, if the gain to the employee exceeds the expected penalty, the employee has the incentive to use the confidential information without complying with the contract. The incentive to breach is increased to the extent that post-employment restraint agreements are not enforceable. See Rubin \& Shedd, Human Capital and Covenants Not to Compete, 10 J. Legal Stud. 93, 101 (1981).

12 See infra notes 52-56 and accompanying text. 
reasonableness of post-employment restraint agreements. ${ }^{13}$ First, such agreements are considered anticompetitive ${ }^{14}$ because they restrict both the mobility of skilled workers and the flow of information essential to a competitive economy. ${ }^{15}$ Second, the agreements are considered unfair because employees, who are viewed as unsophisticated or lacking in bargaining strength, are thought frequently to be unable to obtain full payment for the restrictions imposed on their ability to earn a living. ${ }^{16}$ Third, though this argument is not much relied upon today, these agreements were once considered a threat to the economy because they could remove a productive person from the work force. ${ }^{17}$

After briefly discussing the development of the law governing these agreements, this comment examines the validity of the three justifications offered for disparate treatment of post-employment restraints. Whatever merit these rationales may once have had, they no longer justify the reasonableness inquiry. First, the view that such agreements are anticompetitive results from too narrow

13 See, e.g., Mitchel v. Reynolds, 24 Eng. Rep. 347, 348-50 (Ch. 1711) (stating the three policy concerns thought to justify judicial intervention in this class of contracts).

14 See, e.g., Whitmyer Bros., Inc. v. Doyle, 58 N.J. 25, 33, 274 A.2d 577, 581 (1971) (citing state antitrust laws for the proposition that an employer has no protectible interest in limiting competition); 1st Am. Sys., Inc. v. Rezatto, 311 N.W.2d 51, 57 (S.D. 1981) (enforcement of nondisclosure clauses is limited because they vest the owners of information with monopoly power).

1s See, e.g., Dynamics Research Corp. v. Analytic Sciences Corp., 9 Mass. App. Ct. 254, 267, 400 N.E.2d 1274, 1282 (1980) (restricting the use of post-employment restraints "promotes the public interest in labor mobility and the employee's freedom to practice his profession and in mitigating of monopoly"); Reed, Roberts Assocs., Inc. v. Strauman, 40 N.Y.2d $303,307,353$ N.E.2d 590, 593, 386 N.Y.S.2d 677, 680 (1976) ("'O]ur economy is premised on the competition engendered by the uninhibited flow of services, talent and ideas."); see also Restatement (Second) of ConTracts § 188 comment c (1981) ("[T]he likely injury to the public [from a post-employment restraint] may be too great if it is seriously harmed by the impairment of [the employee's] economic mobility or by the unavailability of the skills developed in his employment.").

16 See, e.g., Schmidl v. Central Laundry \& Supply Co., 13 N.Y.S.2d 817, 823 (Sup. Ct. 1939) ("The inequality in bargaining power between employer and employee have [sic] led the Courts to require a stronger degree of necessity before enforcing a covenant not to labor."); Reading Aviation Serv., Inc. v. Bertolet, 454 Pa. 488, 492, 311 A.2d 628, 630 (1973) (the "inherently unequal bargaining positions" of the parties justify close scrutiny of postemployment restraint agreements).

${ }_{17}$ See, e.g., Tarr v. Stearman, 264 Ill. 110, 119, 105 N.E. 957, 961 (1914) (emphasizing public interest in promoting the optimal use of each person's talents); Moorman \& Givens v. Parkerson, 127 La. 835, 838, 54 So. 47, 47 (1911) (overly broad post-employment restraint agreements may cause the, employee to become a public charge); Kadis v. Britt, 224 N.C. 154, 159, 29 S.E.2d 543, 546 (1944) ("grave consequences of unemployment demand that" post-employment restraint agreements "be examined and weighed with care"); Herreshoff v. Boutineau, 17 R.I. 3, 5, 19 A. 712, 712 (1890) (reasonableness inquiry necessary to prevent "unprofitable idleness"). 
an understanding of competition and from the failure to consider the extent to which such agreements foster competition by providing an incentive for research and development. Second, because the employees most likely to be subject to post-employment restraint agreements are highly sophisticated, employer overreaching is usually unlikely. Finally, the composition of the work force is such that society need not fear that these agreements might entirely remove potentially productive workers from the labor market. The comment concludes that abolishing the exceptional treatment of post-employment restraints would make contract law more coherent: the generally applicable doctrine of unconscionability would provide sufficient protection against employer misbehavior.

\section{The Development of the Law Governing Post-Employment Restraint Agreements}

Post-employment restraint agreements historically have been governed by judge-made law. ${ }^{18}$ The origins of the modern approach to post-employment restraint agreements are found in several English decisions dating back to the fifteenth century. The first reported case to consider an agreement not to engage in a trade was the Dyer's Case, decided in $1414 .^{19}$ While it is unclear from the report whether the noncompetition agreement at issue arose in the context of a sale of a business or of employment, the case has been cited repeatedly for the proposition that such agreements in either context are void as restraints on trade. ${ }^{20}$ This per se rule was reaf-

18 See Handler \& Lazaroff, supra note 10, at 756-66 (collecting cases). Although several states now have statutes governing the validity of these agreements, they generally codify the judge-made rules. See, e.g., CAL. Bus. \& Prop. CoDE $\S \S 16,600-16,602$ (West 1964); MrcH. Comp. Laws Ann. §§ 445.761, 445.766 (West 1967); N.D. Cent. Code § 9-08-06 (1959).

19 Y.B. Mich. 2 Hen. 5, f. 5, pl. 26 (1414). The report states that the court was of the opinion that because such agreements were illegal, the defendant, who had claimed satisfaction of the obligation, might have demurred. Although the plaintiff was allowed to proceed, the judge reportedly said, "By God, if the plaintiff were here he would go to prison until he paid a fine to the King." ("[P]er Dieu si le plaintiff fuit icy il irra al prison, tanque il ust fait fyne au Roy.") Id. In 1587, a blacksmith was jailed when he sought enforcement of a noncompetition agreement; he was later freed on a writ of habeas corpus, on the ground that the justice of the peace had no authority to imprison him. Regarding the agreement itself, however, the report states that the "Court was clear of opinion, that it was void because it was against law." The Blacksmiths of South Mims, 74 Eng. Rep. 485, 485 (1587).

${ }_{20}$ The Dyer's Case was cited in the sixteenth century for the proposition that express agreements restraining the practice of a trade were invalid per se. In 1578, an action for debt against a merchant's former apprentice for breach of a covenant not to engage in trade was not allowed. Anonymous Case, 72 Eng. Rep. 477 (Q.B. 1578). The report contains no details, but cites the Dyer's Case as authority for refusing to enforce the covenant. For modern cases citing the Dyer's Case, see United States v. Addyston Pipe \& Steel Co., 85 F. 271, 280 (6th Cir. 1898), modified and aff'd, 175 U.S. 211 (1899); Arthur Murray Dance 
firmed in 1602 in Colgate v. Bacheler, ${ }^{21}$ which held void a covenant not to engage in a trade even though the restriction was of limited duration and geographic scope and could be removed by the payment of a sum of money. The court stated that such restrictions are "against the benefit of the commonwealth" and that, regardless of the scope of the restriction, the defendant "ought not to be abridged of his trade and living." 22

The modern approach, replacing per se invalidity with a reasonableness inquiry, first appeared in 1711. In Mitchel v. Reynolds, ${ }^{23}$ the lessor of a bake shop agreed to pay the lessee fifty pounds if the lessor engaged in the trade of baking within the parish for the duration of the term of a five-year lease. Holding the contract enforceable, the court noted that although covenants not to compete are to be presumed invalid, in some circumstances they may be reasonable. ${ }^{24}$ General restraints, which prohibited the practice of a trade throughout the kingdom, "must be void, being of no benefit to either party."2s Limited restraints, on the other hand, which operated only in a particular locale, were considered enforceable if the consideration was sufficient to show that the agreement was reasonable. ${ }^{26}$ Mitchel $v$. Reynolds thus abandoned the rule of per se invalidity of the Dyer's Case, but still subjected the restraint to a rebuttable presumption of invalidity, which could be overcome only if the court deemed the terms of the agreement reasonable. ${ }^{27}$

Studios, Inc. v. Witter, 105 N.E.2d 685, 691 (Ohio C.P. 1952).

2178 Eng. Rep. 1097 (Q.B. 1602).

22 Id. at 1097 .

${ }^{23} 24$ Eng. Rep. 347 (Ch. 1711).

${ }^{24}$ Id. at 351-52. Although the case concerned a covenant incident to the lease of a business, Mitchel also addressed the use of such agreements between employers and employees. The court explained that covenants not to compete have great potential for abuse in the employment context, and that they are thus subject to close scrutiny when so used. Id. at 350. The distinction between covenants incident to the sale of a business and those incident to employment, with less deferential treatment of employment agreements, has remained. See, e.g., Orkin Exterminating Co. v. Dewberry, 204 Ga. 794, 803-04, 51 S.E.2d 669, 675-76 (1949) (public policy requires that workers not be allowed to bargain away their labor mobility, but that restrictive covenants in the sale of a business be enforced in order to promote such sales); Arthur Murray Dance Studios, Inc. v. Witter, 105 N.E.2d 685, 703-04 (Ohio C.P. 1952) (discussing reasons for differing treatment and stating that weight of authority recognizes the distinction).

${ }^{25} 24$ Eng. Rep. at 348 . This statement suggests that general restraints were considered unreasonable per se and therefore void.

${ }^{28}$ Id. The court stated that "a man may, upon a valuable consideration, by his own consent, and for his own profit, give over his trade; and part with it to another in a particular place." Id. at 349 .

${ }^{27}$ Id. at 351 . The court gave three rationales for this approach: that such agreements 
The Mitchel $v$. Reynolds approach has survived virtually unchanged to the present day. ${ }^{28}$ The reasonableness of a restraint is usually determined by balancing the legitimate interest of the employer (which must be more than a mere interest in restraining competition) against the employee's interest in labor mobility. If a court decides that the agreement protects a legitimate interest of the employer, and does so without unduly limiting the employee's mobility, it will be enforced. ${ }^{29}$

restricted the employee's ability to earn a living; that they cost society the services of a productive member; and that they were potentially monopolistic. Id. at 350 .

The courts' abandonment of the per se rule seems to have been motivated by an implicit recognition that all commercial contracts by definition restrain trade and that some agreements that restrict trade in the literal sense may in fact be procompetitive. See United States v. Addyston Pipe \& Steel Co., 85 F. 271, 280-81 (6th Cir. 1898) (applying a Mitchel v. Reynolds-type analysis in a suit brought under $\S 1$ of the Sherman Act), modified and aff'd, 175 U.S. 211 (1899); see also Standard Oil Co. v. United States, 221 U.S. 1, 63-66 (1911) (establishing the rule-of-reason analysis under the Sherman Act). In Herreshoff v. Boutineau, 17 R.I. 3, 4, 19 A. 712, 712 (1890), the Rhode Island Supreme Court discussed how this more sophisticated view of competition led to the abandonment of the per se rule for post-employment restraint agreements:

[After the Dyer's Case,] it was soon found that, to some extent at least, such contracts help rather than harm both public interests and private welfare; that they are necessary to trade itself, in order to secure the sale, at fair value, of an established business, by protecting it against the immediate competition of the seller; also to enable one to learn a trade or get employment from another, free from the risk of having the knowledge and influence thus gained used to the employer's damage; to encourage investment in business enterprises under reasonable safeguards; and for other equally evident reasons.

${ }^{28}$ See supra note 10. The development of the law of restraint of trade in England since Mitchel has paralleled its development in this country. See, e.g., W. SANDERSON, supra note 9, at 25-47 (tracing the development of the law since Mitchel and concluding that "the modern test now approved by the House of Lords is practically an application of the principles laid down in Mitchel $v$. Reynolds to the circumstances of present-day life").

29 In Robbins v. Finlay, 645 P.2d 623 (Utah 1982), a hearing aid distributor unsuccessfully sought to enforce a one-year, statewide noncompetition agreement against a former salesman. The Utah Supreme Court set forth the current standard:

Covenants not to compete are enforceable if carefully drawn to protect only the legitimate interests of the employer. The reasonableness of a covenant depends upon several factors, including its geographic extent; the duration of the limitation; the nature of the employee's duties; and the nature of the interest which the employer seeks to protect such as trade secrets, the goodwill of his business, or an extraordinary investment in the training or education of the employee. ... .

In a general sense, the law balances the nature of the interest of one seeking to enforce such a covenant, whether by injunction or by stipulated damages, against the hardship imposed on the employee as a result of the restraint. . . . Covenants not to compete which are primarily designed to limit competition or restrain the right to engage in a common calling are not enforceable.

Id. at 627 (citations omitted); see also Orkin Exterminating Co. v. Walker, 251 Ga. 536, 537, 307 S.E.2d 914, 916 (1983) ("Covenants against competition which are contained in employment contracts are considered to be in partial restraint of trade and will be upheld only if they are strictly limited in time and territorial effect, and are otherwise reasonable consider- 
Such a balancing approach is inherently subjective and uncertain in application. ${ }^{30}$ This uncertainty is compounded by the fact that courts vary in their treatment of these contracts once they are deemed unreasonable. In most jurisdictions, agreements will be recast to conform to the court's view of what is reasonable under the circumstances. ${ }^{31}$ A second approach, the so-called "blue pencil test," renders agreements with unreasonable terms void, unless the offending provisions are grammatically severable from the contract's reasonable terms..$^{32}$ Finally, some courts will hold a restrictive agreement unenforceable in its entirety if any part of it is found unreasonable. ${ }^{33}$

ing the business interest of the employer sought to be protected and the effect on the employee."); Harwell Enters., Inc. v. Heim, 276 N.C. 475, 480-81, 173 S.E.2d 316, 318-19 (1970) (applying balancing-of-interests analysis). But see Continental Group, Inc. v. Kinsley, $422 \mathrm{~F}$. Supp. 838, 843, 846 (D. Conn. 1976) (granting preliminary injunction against former employee on reasonableness grounds despite broad geographic and temporal scope of agreement).

so Compare Welcome Wagon, Inc. v. Morris, 224 F.2d 693, 700 (4th Cir. 1955) (refusing to enforce five-year noncompetition agreement against former Welcome Wagon hostess), and Briggs v. Boston, 15 F. Supp. 763, 768 (N.D. Iowa 1936) (same), with Welcome Wagon Int'l, Inc. v. Pender, 255 N.C. 244, 248-49, 120 S.E.2d 739, 742 (1961) (enforcing five-year noncompetition agreement against former Welcome Wagon hostess), and Briggs v. Butler, 140 Ohio St. 499, 511, 45 N.E.2d 757, 763 (1942) (same); compare National Hearing Aid Centers, Inc. v. Avers, 2 Mass. App. Ct. 285, 290, 311 N.E.2d 573, 577 (1974) (refusing to enforce two-year noncompetition agreement against hearing aid salesman on ground that no legally protectible interest was at stake), with Sonotone Corp. v. Baldwin, 227 N.C. 387, 39091, 42 S.E.2d 352, 354-55 (1947) (enforcing one-year noncompetition agreement againșt hearing aid salesman/manager on reasonableness grounds without inquiring into nature of information transferred).

s1 See, e.g., Eastern Distrib. Co. v. Flynn, 222 Kan. 666, 675, 567 P.2d 1371, 1379 (1977) (upholding judicial recasting of geographic scope of noncompetition agreement on grounds that "equity should not permit an injustice which might result from total rejection of the covenant merely because the court disagrees with an employer's judgment as to what restriction is necessary to protect his business"); R.E. Harrington, Inc. v. Frick, 428 S.W.2d 945, 951 (Mo. Ct. App. 1968) (allowing Missouri court to rewrite overly broad post-employment restraints to conform to the court's view of what restrictions are reasonable under the circumstances).

${ }^{32}$ See, e.g., Reading Aviation Serv., Inc. v. Bertolet, 454 Pa. 488, 493, 311 A.2d 628, 630-31 (1973) (refusing to enforce, under "blue pencil" test, agreement against key employee). The term "blue pencil test" originated from the traditional use by courts of a blue leaded pencil when examining such agreements. See 6A A. Coris, supra note 6, § 1390, at 67-69 (1962). The blue pencil test allows courts to enforce post-employment restraints in part, while enabling them to avoid "rewriting" the contracts. But because it produces "arbitrary and inconsistent results," Raimonde v. Van Vlerah, 42 Ohio St. 2d 21, 24, 325 N.E.2d 544,546 (1975), the test has been discarded in some jurisdictions in which it was once applied. See, e.g., Ehlers v. Iowa Warehouse Co., 188 N.W.2d 368, 371 (Iowa 1971) (referring to the test as "legalistic"); Solari Indus., Inc. v. Malady, 55 N.J. 571, 585, 264 A.2d 53, 60-61 (1970); Raimonde, 42 Ohio St. $2 \mathrm{~d}$ at 25, 325 N.E.2d at 547.

${ }^{33}$ See, e.g., Rector-Phillips-Morse, Inc. v. Vroman, 253 Ark. 750, 753, 489 S.W.2d 1, 4 (1973) ("when a restriction . . . is too far-reaching to be valid, the court will not make a new 
The reasonableness inquiry that is employed where a post-employment restraint agreement is at issue stands in stark contrast to the general rule of American contract law that courts will not, absent procedural irregularities, reexamine a bargain struck by competent parties. ${ }^{34}$ While one may suspect that more than inertia has sustained the reasonableness approach through centuries of judicial decisionmaking, ${ }^{38}$ it is worth examining closely the rationale

contract for the parties by reducing the restriction to a shorter time or to a smaller area"); Philip G. Johnson \& Co. v. Salmen, 211 Neb. 123, 130-31, 317 N.W.2d 900, 904-05 (1982) (refusing, on grounds of overbreadth, to enforce post-employment restraint against former partner); Note, Post Employment Restraints: An Analysis of Theories of Enforcement, and a Suggested Supplement to the Covenant Not to Compete, 17 Tunsa L.J. 155, 157-60 (1981) (discussing this approach).

3* See E. Allan FARnsworth, ConTracts $\$ 4.1$, at 212 (1982) (attributing reluctance of courts to evaluate substantive fairness of contract terms to the rise of the bargain theory of consideration).

35 One explanation for the longevity of the reasonableness approach is its flexibility: courts may, without changing their analytical framework, change the factors considered relevant in determining what restraints are reasonable. See Samuel Stores, Inc. v. Abrams, 94 Conn. 248, 252, 108 A. 541, 543 (1919) ("The public policy to be applied is the public policy of the present time. The changing conditions of life modify from time to time the reasons for determining whether the public interest requires that a restrictive stipulation shall be deemed void as against public policy."). For example, courts may consider the research and development costs incurred in modern, high-technology fields. See, e.g., Structural Dynamics Research Corp. v. Engineering Mechanics Research Corp., 401 F. Supp. 1102, 1113-14 (E.D. Mich. 1975) (limiting enforcement of express nondisclosure agreements to information that qualifies for trade-secret protection is too restrictive in "an area of knowledge and rapid technological change such as the computer field"); Analogic Corp. v. Data Translation, Inc., 371 Mass. 643, 647-49, 358 N.E.2d 804, 807-08 (1976) (reasonableness of covenants not to disclose information regarding a high-speed data-acquisition module is determined in part by the amount of time it would have taken to reverse engineer the product).

Another explanation that has been advanced for the continued vitality of the eighteenth-century approach is that it is the most economically efficient treatment of this class of contracts. See, e.g., Rubin \& Shedd, supra note 11. Rubin and Shedd argue that both parties to these contracts have an incentive to behave opportunistically. Employees have an incentive to breach by using information acquired from the employer to compete against the employer. Id. at 101. Employers have an incentive to be overinclusive in their claims as to what information an agreement covers. Id. at 101-02. Thus, the argument goes, it is economically efficient to enforce only those contracts that serve legitimate ends. But the incentive to overreach exists in all contracts. Furthermore, the employer's tendency to include in these agreements more information than is "reasonable" presumably can be counteracted before the contract is signed. A breach by the employee, however, can be prevented only by enforcing the contract. The employer may also lower the employee's compensation to account for the possibility of breach, but the usefulness of this tactic is limited by the fact that an employer must compete with others seeking labor services, see infra notes $39-42$ and accompanying text, and by the potentially high value of the information transferred, see infra notes 53-56 and accompanying text, and may only increase the employee's incentive to breach in order to relieve himself of these effective payments. Therefore, the existence of opportunities for overreaching does not justify the reluctance of courts to enforce these contracts without conducting an independent evaluation of their reasonableness. Further, even if the reasonableness approach prevents some overreaching, efficiency analysis should take 
for giving post-employment restraint agreements this special treatment. In the absence of an articulable and cogent justification for this departure from traditional contract principles, the approach should be abandoned.

\section{Rationales for the Special Treatment of Post- Employment Restraint Agreements}

Modern cases rely principally on two rationales to justify the harsh treatment of post-employment restraint agreements: the possibility that such agreements will be used for anticompetitive purposes (the "restraint-of-trade" rationale), and the fear of restricting the employee's ability to earn a living (the "employeeprotection" rationale)..$^{36}$ The cost to society of losing the services of a productive individual (the "loss-to-society" rationale), although occasionally mentioned, is relied upon less frequently. ${ }^{37}$ Implicit in these rationales are certain assumptions regarding the nature of competition and the type of market in which it can prevail, the relative bargaining strength and degree of sophistication of the parties, and the composition of the labor force. These sweeping assumptions, however, do not withstand analysis.

\section{A. The Restraint-of-Trade Rationale}

In assessing the competitive impact of post-employment restraint agreements, two different markets must be considered: the market for employee services and the market for the employer's product. Post-employment restraints are said to facilitate the monopolization of the employment market because they limit the ability of employees to sell their services to the highest bidder. ${ }^{38}$

into account the added costs created by the reasonableness inquiry. See supra text accompanying notes 11-12.

${ }^{36}$ See, e.g., American Broadcasting Co. v. Wolf, 52 N.Y.2d 394, 404, 420 N.E.2d 363, 368,438 N.Y.S.2d 482, 487 (1981) (underlying the strict treatment of post-employment restraints are "the general public policy favoring robust and uninhibited competition[, which] should not give way merely because a particular employer wishes to insulate himself from competition . . . . [and] the 'powerful considerations of public policy which militate against sanctioning the loss of a man's livelihood" ") (quoting Purchasing Assocs. v. Weitz, 13 N.Y.2d 267, 272, 196 N.E.2d 245, 247, 246 N.Y.S.2d 600, 604 (1963)) (citations omitted).

37 Blake, Employee Agreements Not to Compete, 73 Harv. L. Rev. 625, 686 (1960) ("Today, although [the loss-to-society] formulation is still occasionally repeated, the recognized method of decision is that of balancing the employer's claims to protection against the burden on the employee. Once the judgment is made, almost never does a court proceed to consider possible injury to society as a separate matter.").

${ }^{38}$ See, e.g., Dynamics Research Corp. v. Analytic Sciences Corp., 9 Mass. App. Ct. 254, 267, 400 N.E.2d 1274, 1282 (1980) (limiting the enforcement of post-employment restraint 
Once an employee has bound himself to a given employer, he cannot move to a more profitable position or force the employer to pay a competitive price for the employee's services.

This argument assumes in effect that competition for labor can exist only in a spot market ${ }^{39}$ and that all long-term employment contracts are, therefore, anticompetitive. ${ }^{40}$ Prior to entering into such contracts, however, employers must compete for the services of skilled employees. Furthermore, the parties can renegotiate if another employer is willing to pay the employee more than he is making under the agreement with his current employer. ${ }^{41}$ Indeed, these contracts are indistinguishable in their competitive effects from other legitimate long-term commercial contracts. For example, a ten-year output contract binds a supplier of a given commodity for an extended period, thus removing a source of supply from the market. If competition exists at the time that such contracts are entered into, however, the later lack of competition for the goods or services does not render the contract illegal as a restraint of trade. ${ }^{42}$

Because long-term contracts involving factors of production other than labor are presumed valid, the differing treatment of labor must rest on supposedly unique characteristics of employment contracts. Theoretically, an employee may have lacked the sophistication to solicit proposals from other employers before signing a

agreements serves to mitigate monopoly by promoting labor mobility).

so $C f$., e.g., American Broadcasting Co. v. Wolf, 52 N.Y.2d 394, 404, 420 N.E.2d 363, 368,438 N.Y.S.2d 482, 487 (1981) ("Underlying the strict approach to enforcement of these covenants is the notion that, once the term of an employment agreement has expired, the general public policy favoring robust and uninhibited competition should not give way merely because a particular employer wishes to insulate himself from competition . . ..") (citations omitted).

to See Kitch, The Law and Economics of Rights in Valuable Information, 9 J. LEGAL STUD. 683, 688 (1980) ("The question is not whether there will be competition among employers for labor and vice versa, but whether that competition will take the form of a spot market for hours of labor or the form of a single contract for many services.").

11 A specific form of the fallacy [of confusing spot markets with competition, and considering long-term contracts monopolistic, is the argument] that contracts which restrict the right to change employment will prevent labor from moving to its highest valued use. This is not the case, since the parties to the transaction can always retransact. If an employee has a higher valued activity in some other employment, he can offer a payment to his employer to obtain release from his contract, as is done in professional sports.

Id.

42 Output and requirements contracts are enforceable. See U.C.C. § 2-306(1) (1978) (allowing such contracts while imposing a reasonableness limit on the amount of output tendered or quantity demanded); E. FARNSWORTH, supra note 34 , § 2.15. 
given agreement ${ }^{43}$ or lacked the means of obtaining the information needed to compare opportunities. ${ }^{44}$ Although these possibilities are relevant to whether there was in fact competition for employee services in a particular instance, they do not explain how long-term contracts as such are anticompetitive.

Post-employment restraints may also be thought to hinder competition in the employer's product market. By preventing an ex-employee from working within the industry or using information obtained during employment, the employer may remove a potential competitor from the market or deprive an existing competitor of a valuable resource. ${ }^{45}$ As a threshold matter, however, the employer cannot affect competition unless he has a dominant position in the product market. Where an employer lacks significant market power, and therefore is a price taker, no action on its part will have an appreciable and lasting effect on the market price. ${ }^{46}$ Moreover, even a firm with market dominance cannot use such agreements to increase its market power or to charge a higher price

${ }^{43}$ A party's lack of sophistication does not, however, invalidate other kinds of contracts. Such treatment is not, in any event, desirable: it makes the fairness of the exchange, rather than the propriety of the bargaining process, determinative of legality. This standard, applied in the medieval English courts, died with the nineteenth-century application of freemarket economic theory to contract law. See P. ATrYAH, supra note 7, at 61-69.

1 See George Stigler, Information in the Labor Market, in The Organization of INDUSTRY 191, 191-92 (1968). Stigler explains that a single wage for a given task will only exist in a perfectly competitive labor market. In real-world labor markets, a wage differential will exist because workers will not have complete knowledge of the available wages. Thus, the potential employee must expend resources in obtaining wage information. Because of the large number of potential employers in many fields, these search costs may be too high for the potential employee to obtain data on all of the relevant firms. Id. at 201-03.

Beyond information problems, an employee's options might be limited by the industrywide use of restrictive post-employment agreements. While this might lessen the attractiveness of the employee's options generally, it does not lessen the competition among the producers for the worker's services. Moreover, an explicit agreement among employers regarding the terms to be offered to potential employees may constitute a violation of section 1 of the Sherman Act, 15 U.S.C. \& I (1982). Such a cartel, however, could only exert monopsony power (a buyer's power to limit price) if the services of the prospective employees were of greater value to the cartelized industry than to any other. Absent such a disparity in the value of services, employees will sell their labor to industries that do not attempt to reduce wages to the monopsony level. Thus, competition among industries for labor will prevent the collusive use of such agreements in most circumstances.

45 See, e.g., Dynamics Research Corp. v. Analytic Sciences Corp., 9 Mass. App. Ct. 254, 267, 400 N.E.2d 1274, 1282 (1980) (promoting labor mobility fosters competition); First Am. Sys., Inc. v. Rezatto, 311 N.W.2d 51, 57 (S.D. 1981) (restricting the flow of information enhances monopoly).

18 See George Stigler, Restraints on Trade in the Common Law, in The OrganizaTION of INDUSTRY 255, 257-58 (1968) (absent monopoly power, an employer is indifferent to whether a former apprentice competes with him upon termination of the apprenticeship). 
in a given period. Post-employment restraint agreements merely protect valuable information-they do not produce it or prevent a competitor from producing its equivalent. By lowering the cost of producing information, ${ }^{47}$ these agreements would, if anything, decrease the price charged in the products market.

An employer with market dominance, however, may be able to use post-employment restraints to prolong that position by reducing the dissemination of knowledge that would allow others to compete effectively with the employer or by restricting the number of potential competitors. For example, if an employer uses such agreements to prevent the disclosure of information that would allow the duplication of the employer's production methods, he may be able to retain whatever market power is attributable to those methods. Or the employer may attempt to preserve market power simply by preventing the employee from using his skills in competition with the employer. While the employee's ex ante demand for compensation forces the employer to share some of the supracompetitive return, both parties are better off than if the market were competitive.

That a post-employment restraint agreement may preserve an employer's market power by restricting the spread of information does not, however, imply that the agreement is anticompetitive. While competition by way of product imitation and improvement requires the free flow of information, ${ }^{48}$ an unlimited flow of information would allow imitators to share in the benefits from information without incurring the costs necessary to produce the information. To the extent that inventors are prevented from reaping the benefits of the information they develop, they are discouraged from engaging in costly research and development, and competition will suffer because fewer products will be produced. ${ }^{49}$

17 See supra notes 11-12 and accompanying text.

4s See Aronson v. Quick Point Pencil Co., 440 U.S. 257, 262 (1979) (patent law authorizes limited monopoly for new inventions but compels disclosure; this provides an incentive for creativity, yet ensures that when patents expire, monopoly will be quickly dissipated by competition); see also Baird, Common Law Intellectual Property and the Legacy of International News Service v. Associated Press, 50 U. CHI. L. REv. 411, 414 (1983) ("[Imitation makes the inventor] worse off than he would be if he had had an exclusive right to his idea, because his competitors are enjoying the fruits of his labor and are not paying for it. Nevertheless, the public as a whole may be better off, as long as this freedom to imitate does not destroy the incentive for people to come up with new devices.") (footnote omitted).

10 See von Kalinowski, Key Employees and Trade Secrets, 47 VA. L. REv. 583, 584 (1961) ("II]f the employer's trade secrets are not protected from appropriation by the employee or the unscrupulous, research and development will be impaired."); Developments in the Law: Competitive Torts, 77 Harv. L. REv. 888, 947 (1964) ("Favoring protection [of trade secrets] is the economic incentive it provides for continued innovation."). Of course, 
The law of intellectual property attempts to balance these conflicting incentives. Patent law, for example, grants inventors a seventeen-year right to the exclusive use of certain information in exchange for the disclosure of the information. ${ }^{50}$ Trade-secrecy law allows the developer of information that is unique, but insufficiently novel to warrant patent protection, limited property rights to the information. ${ }^{51}$ When post-employment restraints merely protect information to the extent allowed under one of the intellectual property regimes, the agreement is no more anticompetitive than the underlying law.

Not all information, however, is protected by an intellectual property regime. When post-employment restraints are used by a firm with market dominance to prevent the dissemination of information that is not so protected, the anticompetitive effect of the restraint might not be offset by the incentive to produce that justifies the legal protection of information. Where a firm with market dominance uses post-employment restraints to restrict the flow of information that is not legally protectible, such agreements may be anticompetitive.

Nevertheless, post-employment restraint agreements are not used solely to prevent the disclosure of information; they are also used to protect an employer's investment in the training of employees. Training by employers can produce two different kinds of human capital: that which can be used only in the firm providing the training ("specific human capital") and that which can be used in other firms ("general human capital"). ${ }^{52}$ The employee will be willing to bear some of the cost of the latter, but not the former, because training in general skills makes the employee more valuable to all firms in the industry. ${ }^{53}$ Were an employee not willing to accept lower wages in return for training, an employer who in-

even with no official protection for information, development would not cease entirely; inventors would develop their own means of protection, but this would be extremely costly.

[I]f trade secret protection against the faithless employee were abolished, . . . [there would be] an increase in the amount of self-help that innovative companies would employ. Knowledge would be widely dispersed among the employees of those still active in research. Security precautions necessarily would be increased, and salaries and fringe benefits of those few officers or employees who had to know the whole of the secret invention would be fixed in an amount thought sufficient to secure their loyalty.

Kewanee Oil Co. v. Bicron Corp., 416 U.S. 470, 485-86 (1974).

so 35 U.S.C. $\$ \S 1-293$ (1982).

s1 Roger Milgrim, Milgrim on Trade Secrets $\S \S 1.01,2.01$ (1984).

62 See Gary Becker, Human Capital 11-26 (1964).

s3 Id. at 19-37. The employee might bear some of the cost of on-the-job training by directly compensating the employer or by simply accepting lower benefits, such as a lower wage. 
vested in training would suffer a loss of capital if the worker left his employ for that of a competitor. The employee's willingness to finance his acquisition of general human capital provides the employer with the incentive to train his workers in-house, rather than requiring them to seek training elsewhere..$^{34}$

The cost of acquiring general human capital may, however, exceed the worker's ability to pay for it. This problem arises, for example, when very valuable information (which may not qualify as a trade secret) must be disclosed to an employee ${ }^{55}$ or when the training required for a given job is very time-consuming or costly. ${ }^{56} \mathrm{In}$ these instances, once the employer has provided the training, he still must recoup the uncompensated portion of his investment. Because a competing firm has not financed the acquisition of the skill or the development of the information, it can offer greater compensation than that offered by the initial employer. Consequently, the employee will have an incentive to leave for a competitor after acquiring general skills and knowledge, at the employer's expense, but before the employer has a chance to receive a return on his investment.

The employer's only means of protecting his investment in such capital is to prevent the employee from using his training or divulging the acquired information for a given period. By so doing, the employer effectively can convert the general human capital that he has financed into specific human capital. Legal rules that render express post-employment restraints invalid may, by remov-

st Id. at 19-26. No trade-secret protection is accorded information that merely embodies the general skills or knowledge obtained by an employee. See, e.g., Schulenburg v. Signatrol, Inc., 33 Ill. 2d 379, 387, 212 N.E.2d 865, 869 (1965) ("It is clear that an employee may take with him, at the termination of his employment, general skills and knowledge acquired during his tenure with the former employer. It is equally clear that the same employee may not take with him confidential particularized plans or processes . . . ."), cert. denied, 383 U.S. 959 (1966); Operations Research, Inc. v. Davidson \& Talbird, Inc., 241 Md. 550, 568, 217 A.2d 375, 385-86 (1966) (finding that employees of an operations-research company had taken only increased general skills and experience from the firm); Junker v. Plummer, 320 Mass. 76, 79-80, 67 N.E.2d 667, 669 (1946) (former employees who built a replica of former employer's shoe-manufacturing machine were found to have taken more than the allowable "general skill or knowledge").

ss See Rubin \& Shedd, supra note 11, at 96-97 (citing example of trade secret that may be taught to a worker in one day, but that is worth $\$ 100,000$ to the employer).

so Some employers may be able to circumvent this problem. For example, because an airline cannot contractually bind trainees for the period required to recoup its investment in training, it relies heavily on the military, which can bind employees, to train pilots. See G. BECKER, supra note 52 , at 17 (well over $90 \%$ of the country's commercial pilots were trained in the military). Another example is the M.D. or Ph.D. candidate who binds himself to a lengthy period of research at the university that grants him the degree in exchange for a heavily subsidized education. 
ing the employer's only means of protecting his investment, hurt the competitive process by discouraging investment in human capital.

Thus, post-employment restraints are potentially anticompetitive only in narrowly defined circumstances. First, the employer must have market power in order for his actions to have an effect on competition. Second, even where the threshold market position exists, the post-employment restraint is not anticompetitive if it covers information that the employer has a legal right to protect. Where legally protectible information is involved, inquiry into geographic markets, the reasonableness of the time restraints, and the relative bargaining strengths of the parties is irrelevant; it is a waste of judicial resources and a potential source of judicial errors. And, finally, even where no protectible information is at issue, the agreement is not necessarily anticompetitive because post-employment restraints can protect the employer's investment in human capital as well as in information.

Because competition in the employment market is not hindered by post-employment restraint agreements, and because competition in the product market is adversely affected only in a small class of cases, neither a presumption of invalidity nor a broad reasonableness inquiry is appropriate. Treatment according to general contract principles is both less intrusive and less costly. And when conditions are such that an anticompetitive use of a restraint occurs, relief is available under the antitrust laws. ${ }^{57}$

\section{B. The Employee-Protection Rationale}

The employee-protection rationale for scrutinizing post-employment restraint agreements rests on the importance of the personal freedom or mobility of workers. ${ }^{58}$ But personal freedom in-

${ }^{87}$ The federal antitrust laws are broadly phrased to prohibit most anticompetitive activity. See 15 U.S.C. $\S \S 1-31$ (1982). While section 1 of the Sherman Act, 15 U.S.C. $\S 1$ (1982), which bars all contracts, combinations, and conspiracies in restraint of trade, would extend by its terms to post-employment restraint agreements, the Supreme Court's recent rejection of the intra-enterprise conspiracy doctrine, see Copperweld Corp. v. Independence Tube Co., 104 S. Ct. 2731 (1984), suggests that employers could not be sued under section 1 over such agreements. Section 2, however, applies to unilateral action when monopoly is achieved or attempted. 15 U.S.C. \& 2 (1982). Because post-employment restraints are only potentially anticompetitive where significant market power already exists, section 2 should provide a basis for antitrust liability where actual competitive harm is threatened.

${ }^{88}$ See, e.g., Schmidl v. Central Laundry \& Supply Co., 13 N.Y.S.2d 817, 823 (Sup. Ct. 1939) (English and American precedent indicate that the liberty of the employee is of primary importance in assessing the policy implications of post-employment restraint agreements); Arthur Murray Dance Studios, Inc. v. Witter, 105 N.E.2d 685, 692 (Ohio C.P. 1952) 
cludes freedom of contract, and the freedom to contract by definition allows the voluntary restriction of one's options. ${ }^{59} \mathrm{In}$ deed, all contracts, by imposing obligations, limit choices to some extent. Nevertheless, agreements between competent parties are enforced routinely and without judicial inquiry into whether one or the other party got the better of the bargain; ${ }^{80}$ in order to justify the special treatment accorded post-employment restraint agreements, some characteristic peculiar to the employment relationship needs to be found. ${ }^{61}$

The employee-protection argument implicitly assumes that employees as a class are unable to protect themselves against overreaching by employers: if employees are able to secure adequate consideration for the options they relinquish, then clearly no protection, beyond that provided under general contract rules, is needed. ${ }^{62}$ Accordingly, the courts that have formulated this rationale have usually attributed the need for judicial protection of employees to a perceived inequality of bargaining power between the parties. ${ }^{63}$ Other cases imply that employees as a group are less so-

(courts ask whether the agreement is "unduly harsh and oppressive on the employee").

s9 Not everyone accepts autonomy as the normative basis for contract law; some commentators favor the use of contract law to advance paternalistic or distributive goals. See, e.g., Kennedy, Distributive and Paternalistic Motives in Contract and Tort Law, with Special Reference to Compulsory Terms and Unequal Bargaining Power, $41 \mathrm{MD}$. L. Rev. 563 (1982); Kronman, Contract Law and Distributive Justice, 89 YaLe L.J. 472 (1980) [hereinafter cited as Kronman, Distributive Justice]; Kronman, Paternalism and the Law of Contracts, 92 Yale L.J. 763 (1983) [hereinafter cited as Kronman, Paternalism and Contracts]. Under such an agenda, an independent judicial determination of reasonableness may be not only permissible, but desirable. See also Comment, Covenants Not to Compete: A Survey of Kansas and Missouri Law, 53 UMKC L. REv. 237, 256 (1985) (arguing that the present reasonableness inquiry should be made even more protective of employees).

so See 1 A. Corbin, supra note $6, \S 127$ (courts do not inquire into the adequacy of consideration in the absence of special circumstances indicative of fraud, mistake, or undue influence).

-1 While some courts have drawn an analogy to the prohibition against selling oneself into slavery, e.g., Oak Cliff Ice Delivery Co. v. Peterson, 300 S.W. 107, 111 (Tex. Civ. App. 1927) (special scrutiny necessary to avoid "industrial servitude"), the nature of the restraint is fundamentally different. Rather than compelling labor, such agreements merely restrict the options of the former employee in selecting a new place of employment.

-2 Even if employees as a class are disadvantaged, this basis for disparate treatment is valid only if paternalism is a legitimate reason for interfering with private contracts. $C f$. Kronman, Paternalism and Contracts, supra note 59, at 765 (arguing that paternalism is a valid reason for contract regulation). But even if, as a normative matter, paternalism may be an appropriate basis for invalidating contracts, the kinds of employees most likely to enter into post-employment restraint agreements are in no need of such protection. See infra notes $67-70$ and accompanying text.

os See, e.g., Wheelabrator Corp. v. Fogle, 317 F. Supp. 633, 638 (W.D. La. 1970) (unequal bargaining power limits an agreement's weight in assessment of whether employee knew secret business information was at stake); Schmidl v. Central Laundry \& Supply Co., 
phisticated than employers, and thus may not be able to judge what is in their own best interest. ${ }^{64}$

Quantifying bargaining power or sophistication, which is necessary for assessing the validity of these assumptions, is difficult. ${ }^{65}$

13 N.Y.S.2d 817, 823-24 (Sup. Ct. 1939) ("inequality in bargaining power . . . have [sic] led the Courts to require a stronger degree of necessity before enforcing a covenant not to labor" as opposed to a covenant regarding the sale of a business); Arthur Murray Dance Studios, Inc. v. Witter, 105 N.E.2d 685, 704 (Ohio C.P. 1952) ("The average, individual employee has little but his labor to sell or to use to make a living. He is often in urgent need of selling it and in no position to object to boiler plate restrictive covenants placed before him to sign."). But see Robbins v. Finlay, 645 P.2d 623, 627 (Utah 1982) (bargaining strength found to be sufficiently equal to allow enforcement of a liquidated damages clause in a postemployment restraint agreement).

64 See, e.g., Samuel Stores, Inc. v. Abrams, 94 Conn. 248, 253, 108 A. 541, 543 (1919) (restraints incident to the sale of a business treated more leniently than post-employment restraints because of greater "parity in ability to negotiate"); Standard Oil Co. v. Bertelsen, 186 Minn. 483, 484-85, 243 N.W. 701, 702 (1932) (citing disparity of sophistication between Standard Oil and an unskilled laborer in refusing to enjoin breach of noncompetition agreement).

The general principles of contract law provide better guidance to evaluate inequities of bargaining power or sophistication. The grounds for invalidation of other types of contracts fall, roughly, into two groups: those related to the failure of the parties to fulfill the procedural requirements of contract formation and those related to the capacity of the parties to contract. See E. FARNSWORTH, supra note $34, \S 4.1$, at 213 (characterizing this dichotomy as one between behavior, which focuses on the conduct of the bargaining process, and status, which focuses on the parties' characteristics). Contract invalidation based upon inequality of bargaining power is most clearly analogous to the procedural defect of duress. A person's economic condition may be sufficiently perilous that he has no real alternative to accepting employment on the terms offered. The duress doctrine as it now stands, however, does not extend to economic pressure, see, e.g., United States v. Bethlehem Steel Corp., 315 U.S. 289, 300-05 (1942) (rejecting government's argument that pressing need for ships during World War II resulted in shipbuilding contracts that were the product of economic duress), and its application to post-employment restraint agreements, by almost presuming them to be the product of duress, is anomalous. Moreover, in the extreme case, where the employee truly is forced to accept the employment agreement involuntarily, the generally applicable doctrine of unconscionability would provide sufficient protection. See infra notes 85-91 and accompanying text. A claim of lack of sophistication is analogous to the common law doctrine of incapacity. See E. FARNSWORTH, supra note $34, \S 4.2$, at 214 (incapacity is "an inability to participate meaningfully in the bargaining process"). An employee who is so unsophisticated that he cannot appreciate the nature of the restriction may be viewed as lacking the capacity to assent meaningfully to the terms offered. See Kronman, Distributive Justice, supra note 59, at 478-83 (lack of capacity to assent in a meaningful way underlies all claims of coercion by those seeking to invalidate contracts). It must be rare, however, that an adult employee who is so valuable that his employer will seek an agreement restricting his postemployment opportunities will also be incapable of freely and knowingly entering into a contract.

${ }_{65}$ Viewing bargaining power in purely economic terms, for example, ignores the subjective element inherent in all negotiations. The strength of each party's desire to reach an agreement and the strength of any conflicting desires or considerations influence the relative bargaining position of each. An indifferent buyer is presumably willing to pay less for a product than is an eager one, and an anxious seller presumably will accept less than an indifferent one. While lack of resources may preclude some from bargaining for an item at 
Even confidence in judges' ability to quantify inequities and draw a line to indicate when they are excessive would not necessarily justify a presumption of invalidity. Most contracts are negotiated by parties with unequal bargaining power and unequal shrewdness, yet courts do not invalidate or rewrite ordinary contracts on these grounds. ${ }^{66}$ Therefore, one must find additional factors to justify the refusal to apply, in the post-employment restraint cases, the rules generally applicable to contracts between competent persons. There are two possible explanations. First, the relative bargaining positions or sophistication of the parties may be considered so disproportionate that inequities sufficient to render the agreements unenforceable, under general contract principles, exist in enough cases to justify the costs of a reasonableness inquiry. Second, the values sought to be protected-freedom to engage in the work of one's choice and to alter that decision at will-may be thought sufficiently powerful to justify the costs of heightened scrutiny regardless of the frequency with which overreaching occurs.

An assessment of the kinds of employees likely to enter into express post-employment restraint agreements suggests that the fear that these employees are unable to protect themselves is misplaced. ${ }^{67}$ Generally, information worth protecting by contract is, because of its value, not widely dispersed throughout a firm. ${ }^{68}$ One can expect that sensitive information would tend to be in the possession of more highly skilled employees. To the extent that such employees can be presumed to be relatively sophisticated and to

all, bargaining strength cannot be measured in purely economic terms beyond this threshold point. The subjective element of bargaining power may account for the absence of unequal bargaining power as a ground for interference with contractual terms at common law. See $R$. PoSNER, supra note 8 , at 87 (the concept of bargaining power is meaningless as a guide to the enforceability of contracts).

o6 The open-ended unconscionability grounds for invalidation, both under the equitable doctrine, see Coles v. Trecothick, 32 Eng. Rep. 592, 597 (1804) (equity will not grant specific performance of an agreement which "shocks the conscience"), and under the Uniform Commercial Code, U.C.C. \$ 2-302 (1978) (quoted infra note 86), can be used to take these factors into account in extreme cases. See infra notes 85-91 and accompanying text.

${ }^{67}$ See Kitch, supra note 40, at 687-88 (accepted use of post-employment restraint provisions in professional sports, entertainment, and military enlistment contracts undercuts incapacity justification for presumptive invalidity). Of the three examples cited by Kitch, military enlistment is the most interesting. The other two might be distinguished from the bulk of post-employment restraint agreements by the relative wealth and sophistication of employees engaged in sports and entertainment. Many military recruits, however, almost certainly do not fully appreciate the consequences of a binding commitment to military service; absent clear incapacity, such agreements are enforced.

${ }^{8}$ Cf. Kewanee Oil Co. v. Bicron Corp., 416 U.S. 470, 482 (1974) (trade-secret protection enhances economic efficiency by allowing "dispersion of responsibilities for creative developments" throughout large firms). 
have alternative employment opportunities, the fear of overreaching by employers diminishes. ${ }^{69}$ While not all employees with access to valuable information may be considered to fall into this class, ${ }^{70}$ the issue is not whether employers ever have the incentive and opportunity to overreach in using these agreements, but whether the circumstances in which such overreaching is successful exist frequently enough to warrant the costs of a reasonableness inquiry. The issue is not whether employees ought to be protected in the event of overreaching, but whether one should presume that overreaching is widespread.

The special treatment accorded post-employment restraints, to the extent that it depends on the relative bargaining strengths of the parties, is puzzling in its protection of persons who are able, ex ante, to assess the desirability of the terms, who are able to foresee the consequences of such terms, and who are free not to contract if the terms are sufficiently unfavorable. Even under the common law doctrines excusing performance by reason of mutual mistake or impossibility, the mistake or impossibility must have become known after the contract was made, and must have been unforeseeable, in order for performance to be excused. ${ }^{71}$ Thus, in a

69 See, e.g., Continental Group, Inc. v. Kinsley, 422 F. Supp. 838, 843-44 (D. Conn. 1976) (multinational restriction reasonable in part because sophisticated employee freely chose to accept sensitive position with knowledge of restrictive covenant). But see, e.g., Reading Aviation Serv., Inc. v. Bertolet, $454 \mathrm{~Pa}$. 488, 311 A.2d 628 (1973) (agreement not to compete found unenforceable despite the employee's having been chairman of the board, president, and a large stockholder of his corporate employer). Even highly sophisticated employees with numerous employment options may, however, have little bargaining power where use of post-employment restraint agreements is industry-wide. Because such employees could apply their skills in other industries, the competition among industries for skilled workers should limit this form of overreaching. The antitrust laws provide additional protection. See supra note 44.

${ }^{70}$ For example, low-level manufacturing employees may have access to machinery or processes that constitute trade secrets. Much early twentieth-century trade-secret litigation involved such employees. See supra note 1.

${ }^{71}$ The excuse doctrines rest upon the notion that contracts are negotiated under implicit assumptions, and performance may be excused if the assumptions are later found to have been incorrect. For example, in Sherwood v. Walker, 66 Mich. 568, 33 N.W. 919 (1887), the court allowed rescission of a contract for the sale of a cow because the mutual assumption that the cow was barren turned out to be mistaken. For more recent cases discussing the mistake doctrine, see Leasco Corp. v. Taussig, 473 F.2d 777, 781-82 (2d Cir. 1972) (poor prediction of one party's future earnings does not excuse performance under the mistake doctrine); Dover Pool \& Racquet Club, Inc. v. Brooking, 366 Mass. 629, 633-34, 322 N.E.2d $168,170-71$ (1975) (mistaken assumptions regarding applicable zoning laws are grounds for excusing performance).

In Taylor v. Caldwell, 122 Eng. Rep. 309 (1863), the court reasoned that the continued existence of a concert hall was an implied condition of a contract to rent the hall, thus excusing performance, on the ground of impossibility, when the hall was destroyed by fire. For more recent impracticability cases, see Gulf Oil Corp. v. F.P.C., 563 F.2d 588, 598-600 
legal system in which great importance is usually attached to the notion of fault, ${ }^{72}$ it is surprising that a post-employment restraint agreed upon with knowledge of one's disadvantage is more easily avoided than a contract in which foreknowledge was impossible.

This incongruity suggests that the differential treatment of post-employment restraints is explained not by a defect in the formation of these contracts, but by the perception that the freedom to seek employment is so important a right that agreements restricting its exercise, even if entered into deliberately and knowingly, should be enforced only with considerable caution, regardless of the increased transaction costs. ${ }^{73}$ While this argument may explain the reasonableness inquiry, it does not justify it. This solicitous treatment of employees assumes that they are both fungible and overabundant. If the employees most likely to enter into these agreements are sophisticated persons who can bargain with various employers for the best available terms, the social loss from this excess of caution may well exceed the gain. Such persons have given up a valuable right, but they have freely bargained for the contract and have been compensated for accepting the terms. Although the current rule works to the advantage of true victims of overreaching, the protection afforded is overinclusive. Enforcement of this class of contracts according to general contract principles would not deprive skilled, sophisticated workers of any freedom that they did not freely bargain away. As for those employees who so lacked other job opportunities that assent in a real sense may not have been given, the general principles of modern contract law would protect them adequately. ${ }^{74}$

(3d Cir. 1977) (economic inability to perform does not constitute impracticability); Louisiana Power \& Light Co. v. Allegheny Ludlum Indus., 517 F. Supp. 1319, 1323-24 (E.D. La. 1981) (unanticipated loss of profits does not render contract unenforceable on impracticability grounds unless especially severe and unreasonable); see also U.C.C. \& 2-615 (1978) (codifying doctrine in terms of failure of presupposed condition). Because these doctrines apply only where a mutual implied assumption is or turns out to be incorrect, they do not extend to situations in which one party merely has second thoughts about the wisdom of his bargain.

${ }^{72}$ See W. Kegton, D. Dobrs, R. Keeton \& D. Ofen, Prosser and Keeton on the Law of TorTs $\S 28$ (5th ed. 1984) (discussing the history of the fault concept in tort law); W. LaFave \& A. ScotT, Handbook on Criminal Law \& 27 (1972) (discussing the mens rea requirement in criminal law); Epstein, $A$ Theory of Strict Liability, 2 J. LEGAL STUD. 151, 15253 (1973) (despite an early preference for strict liability in tort at early common law, fault was generally required for tort liability by the nineteenth century).

73 See Blake, supra note 37 , at 650 (the values at issue are social or political rather than economic); see also Oak Cliff Ice Delivery Co. v. Peterson, 300 S.W. 107, 111 (Tex. Civ. App. 1927) (discussing the "inherent right to labor").

74 See infra notes 81-91 and accompanying text. 


\section{The Loss-to-Society Rationale}

Another reason sometimes offered as a justification for the harsh treatment of post-employment restraints is that society should not be deprived of the services of one of its productive members. In eighteenth-century England, this concern may have been legitimate. Because of the smaller population, ${ }^{75}$ the impact of the various plagues that devastated the English population during the seventeenth and eighteenth centuries, ${ }^{76}$ and limited labor mobility, the removal of a skilled person from the work force, even if beneficial to the parties, might have exacted significant social costs. Moreover, the guild system made it difficult, if not impossible, for a displaced employee to change occupations. ${ }^{77}$

Under present-day economic conditions, however, this rationale does not support the disparate treatment of express post-employment restraint agreements. ${ }^{78}$ There is no general shortage of labor, and shortages of workers with any given skill can be remedied by training others. ${ }^{79}$ Although in a literal sense society is deprived by these agreements of the benefit of having a skilled worker engaged in a given trade, ${ }^{80}$ the agreements do not, as they

75 The population of England in 1700 has been estimated at 5,134,516. By 1880, this figure had risen to $25,480,161$. William Cunningham, The Growth of English Industry AND COMMERCE 465-66 (1885).

78 Although the initial outbreak of bubonic plague struck England in the mid-fourteenth century, the disease, once introduced into the country, frequently returned. See EDward Cheyney, An Introduction to the Industrial and Soctal History of England 10104 (1916).

${ }^{73}$ See generally Stella Kramer, The English Craft Gilds (1927). Cf. Blake, supra note 37, at 637 (per se rule of the Dyer's Case was an attempt to preserve the status of the craft guilds by precluding the alteration of the customary master-apprentice relationship).

${ }^{78}$ See Arthur Murray Dance Studios, Inc. v. Witter, 105 N.E.2d 685, 691 (Ohio C.P. 1952) (changes in the law governing post-employment restraints are attributable to changed "social, economic, industrial, communication and transportational" conditions); Blake, supra note 37 , at 638 (industrial revolution lessened the barriers to individuals' shifting occupations and increased the geographic mobility of workers, thereby lessening the harshness of post-employment restraints).

${ }^{7 \theta}$ In fact, labor-shortage problems had disappeared at least by the turn of the twentieth century. See Herreshoff v. Boutineau, 17 R.I. 3, 6-7, 19 A. 712, 713 (1890) (comparing late-nineteenth-century American employment conditions with those of eighteenth-century England).

${ }^{80}$ Although, with the demise of the trade guilds, a post-employment restraint may not completely bar a person from working, a loss to society will result if he is unable to put his talents to their optimal uses. The extent of the resultant welfare loss depends upon the frequency with which an employee's skills are so specialized that they are worth considerably more to one industry than to another. The welfare loss incident to post-employment restraints is thus analogous to that which arises from monopsony, i.e., it only occurs where the value of the input is particularly high in one industry. See supra note 44 . Because employees with such specialized skills will earn less under a post-employment restraint than 
might have in the eighteenth century, preclude gainful employment of the worker.

\section{The Enforcement of Post-Employment Restraint Agree- ments According to General Contract Principles}

The preceding analysis indicates that no persuasive rationale has been advanced for subjecting post-employment restraint agreements to an independent judicial determination of reasonableness. In the absence of such a showing, the well-established principles that ordinarily govern contracts between competent parties should be applied to these agreements. This is not to say that employer misconduct should go unchecked-on the contrary, the doctrine of unconscionability provides an appropriately limited mechanism for protecting employees in those narrow circumstances where judicial scrutiny of contracts is actually justified.

The nineteenth-century notion of sanctity of contract compelled enforcement absent a verifiable and recognized excuse. ${ }^{\text {11 }}$ Unless physical duress, fraud, mental incapacity, or infancy could be shown, traditional contract principles required an employee to live with the bargain he made, regardless of how disadvantageous the terms. ${ }^{82}$ Like the refusal to assess the sufficiency of consideration, the refusal to examine the fairness of contracts stemmed in part from the difficulty of conducting such a subjective inquiry. ${ }^{83}$ Conceptually more significant, however, was the notion of freedom of contract. As has often been said, the freedom to contract includes the "freedom to make a bad bargain." gime, employer overreaching through the use of express post-employment restraints, absent some procedural irregularity, could not be remedied.

Despite the conceptual elegance of the nineteenth-century view of contract, courts eventually began to examine the substantive terms of contracts in cases of extreme unfairness. Under the doctrine of unconscionability, as it originated in the nineteenth century, an agreement that "shocked the conscience" would not be

they would otherwise, they have an incentive to renegotiate with their former employers, thus removing the welfare loss in those relatively rare cases in which it would otherwise arise.

s1 See P. AtryaH, supra note 7, at 388-89 (discussing the rise of formalism and the decline of equity in the nineteenth century).

82 See E. FARnsworth, supra note 34, § 4.1; Epstein, supra note 6, at 315.

${ }^{83}$ See supra note 65 and accompanying text.

B4 E.g., Sanger v. Yellow Cab Co., 486 S.W.2d 477, 482 (Mo. 1972). 
enforced in a court of equity. ${ }^{85}$ The twentieth-century notion of unconscionability is codified in section 2-302 of the Uniform Commercial Code. ${ }^{86}$ This provision and the cases decided thereunder offer guidance as to what conduct is to be deemed unconscionable. Although the text of the Code contains no explicit definition of the term, ${ }^{87}$ the official commentary states as the basic test "whether, in the light of the general commercial background and the commercial needs of the particular trade or case, the clauses involved are so one-sided as to be unconscionable under the circumstances existing at the time of the making of the contract." 88 This concern with the one-sidedness of the terms of an agreement suggests that unconscionability may provide a means of preventing employer overreaching within the general framework of contract law.

The cases decided under section 2-302 afford a clearer picture of the relevant considerations in an unconscionability inquiry. The most influential judicial statement of what constitutes unconscionability combines both the procedural and substantive aspects of the term. ${ }^{89}$ In Williams $v$. Walker-Thomas Furniture Co., ${ }^{90}$ the

so See, e.g., Marks v. Gates, 154 F. 481, 483 (9th Cir. 1907) (grant, in discharge of indebtedness, of contingent interest in an undetermined sum held unconscionable); Coles v. Trecothick, 32 Eng. Rep. 592, 597 (1804) (stating the traditional "shock the conscience" test for equitable unconscionability). For a criticism of unconscionability as a standard by which to judge the substantive fairness of contract terms, see Epstein, supra note 6, at 293-95.

8s U.C.C. \$ 2-302 (1978) provides:

(1) If the court as a matter of law finds the contract or any clause of the contract to have been unconscionable at the time it was made the court may refuse to enforce the contract, or it may enforce the remainder of the contract without the unconscionable clause, or it may so limit the application of any unconscionable clause as to avoid any unconscionable result.

(2) When it is claimed or appears to the court that the contract or any clause thereof may be unconscionable the parties shall be afforded a reasonable opportunity to present evidence as to its commercial setting, purpose and effect to aid the court in making the determination.

Although limited by its terms to sales transactions, section 2-302 has been extended by analogy to render other types of contracts unenforceable. See, e.g., Weaver v. American Oil Co., 257 Ind. 458, 461-64, 276 N.E.2d 144, 146-48 (1971) (gas station lease); Zapatha v. Dairy Mart, Inc., 381 Mass. 284, 291-94, 408 N.E.2d 1370, 1375-77 (1980) (franchise agreement); see also CaL. Civ. Code $§ 1670.5$ (West 1985) (statutory extension); Restatement (SEcond) of CoNTRACTS $\S 208$ (1981) (discussing unconscionability in terms of U.C.C. article 2 but without limiting its scope to sales transactions).

${ }^{87}$ Because it facilitates the application of the doctrine to unforeseen instances of unfair bargaining, this failure to define the term is considered by some to be a virtue. See, e.g., Ellinghaus, In Defense of Unconscionability, 78 YALE L.J. 757, 814-15 (1969).

${ }_{88}^{8}$ U.C.C. § $2-302$ comment 1 (1978).

89 The procedural/substantive distinction, first set forth in Leff, Unconscionability and the Code-The Emperor's New Clause, 115 U. PA. L. Rev. 485, 487-89 (1967), has been widely adopted. See, e.g., Hillman, Debunking Some Myths About Unconscionability: A New Framework for U.C.C. Section 2-302, 67 CoRnelu L. Rev. 1, 2-5 (1981) (discussing the 
District of Columbia Circuit stated that unconscionability includes "an absence of meaningful choice on the part of one of the parties together with contract terms which are unreasonably favorable to the other party." The "absence of meaningful choice" standard would prevent interference with post-employment restraints for skilled and sophisticated employees, and the "unreasonably favorable" prong of the test would permit a reasonableness inquiry in the occasional case involving a genuinely disadvantaged employee.

\section{ConcLusion}

The reasonableness approach to post-employment restraint agreements, which is contrary to the general rule that courts will not examine the substantive fairness of contract terms, has remained virtually unchanged since 1711 , although the stated rationales for this approach no longer withstand analysis. Post-employment restraint agreements are not anticompetitive per se, and in fact may foster competition by affording employers needed protection for confidential business information or investments in training. The fact that such agreements are most likely to be used with high-level employees and in industries involving complex technologies suggests that employer overreaching is not pervasive enough to warrant special treatment of these contracts as a class. And, finally, because of social and economic changes, there is little likelihood that these agreements exact significant societal costs. Because contracts that are anticompetitive can be invalidated under the antitrust laws, and because the doctrine of unconscionability

doctrine in these terms while criticizing Leff's analysis); Epstein, supra note 6, at 305-06. The former term refers to the fairness of the negotiations, and the latter refers to the fairness of the terms ultimately agreed upon.

so 350 F.2d 445 (D.C. Cir. 1965).

9 Id. at 449. A similar standard was applied in Kugler v. Romain, 58 N.J. 522, 544, 279 A.2d 640, 652 (1971) ("The intent of the [unconscionability] clause is not to erase the doctrine of freedom of contract, but to make realistic the assumption of the law that the agreement has resulted from real bargaining between parties who had freedom of choice and understanding and ability to negotiate in a meaningful fashion."), and in Allen v. Michigan Bell Tel. Co., 18 Mich. App. 632, 637, 171 N.W.2d 689, 692 (1969) ("Implicit in the principle of freedom of contract is the concept that at the time of contracting each party has a realistic alternative to acceptance of the terms offered."). See generally Hillman, supra note 89, at 4-5 (suggesting that common law assent doctrine provides guidance for cases involving unconscionable behavior in the bargaining process). 
could adequately protect vulnerable employees, employer excesses can be restrained without incurring the economic and social costs of continuing to apply the Mitchel $v$. Reynolds analysis.

Maureen B. Callahan 